\title{
The Effectivity of Making Ethanol By Cassava Skin Waste Using Bread and Tapai Yeast as Activator
}

\author{
$1^{\text {st }}$ Khairil Anwar \\ Environmental Health Departemen \\ Poltekkes Palembang \\ Palembang, Indonesia \\ Khairilanwar46@ymail.com.
}

\author{
$2^{\text {nd }}$ Sukarjo \\ Environmental Health Departemen \\ Poltekkes Palembang \\ Palembang, Indonesia \\ gantengsukarjo@gmail.com
}

Corresponding author : Khairilanwar46@ymail.com

\begin{abstract}
Waste is an unused material by the previous owner, anyway the waste can reused by managing it properly. The Problem In big cities commonly waste that comes from settlements and traditional markets. Most of the waste produced by traditional markets $(95 \%)$ is organic waste. The way to overcome the problem of waste by recycle or reuse it. One of waste that able to be ethanol by using manufacture methods. The process to beethanol accelerated by adding activators that material content of microorganisms (bacterial culture), mold and yeast.This study was a true Experimented design post-test that aims to determined the dosage and time of ethanol was produced from cassava skin waste using bread and tapai yeast as activators. This study used $\mathbf{3 0 0}$ grams of cassava skin waste plus $100 \mathrm{ml}$ of distilled water and each added three different types of bread yeast doses and tapai yeast each $1.35 \mathrm{mg}, 2.25 \mathrm{mg}$ and $3.15 \mathrm{mg}$. Each activator performed a bivariate statistical test by using the $T$ independent test with a significant level of $5 \%(0.05)$. This research was conducted at the Environmental Health Departemen Laboratory of the Polytechnic of Health in Palembang and at the Laboratory of the Pharmacy College of Bhakti Pertiwi Palembang on July-December 2019. The results showed that the most effective time to produce ethanol by usingtapai yeast activator. The most effective amount of ethanol produced by using tapai yeast activator. The conclusions of this research show that the tapai yeast activator is more effective way to produce ethanol than bread yeast activator. The recommended to make ethanoluse cassava skin waste andtapai yeast as activator.
\end{abstract}

Keywords - Cassava Skin Waste, Ethanol, Bread and Tapai Yeast.

\section{INTRODUCTION}

The Garbage were avoided things that everytime generated by our daily activities. According to the Big Indonesian Dictionary, waste is defined as items or objects that are discarded because they are not use longer anymore. By thelaw Number 18 of 2008 concerning Was Management, the waste is the residue of daily human activities and / or solid natural processes. They produced from various sources, namely household activities, industry, offices, agriculture / plantations, public facilities and mining. The waste becomes a big problem if it is not managed properly. If it is left there will be a mountain of rubbish which able be disrupt the health and beauty of the city. Elsewhere, the same problem will also be experienced, for example in areas close to the Landfill.

The wasteable to be twogroups, namely organic waste and inorganic waste. Organic waste has the biggest contribution in the accumulation of waste. Organic waste for example is leaf litter, food scraps, animal waste and others. it has a great potential to be reused into useful goods and significant economic value.

Utilization of alternative energy is being promoted to reduce dependence on fuel oil (BBM), one of which is the use of bioethanol. Bioethanol is derived from the fermentation of corn, sago, papaya, sugar cane, pineapple and the like. Bioethanol can be used as a solvent. The content in bioethanol is ethanol (alcohol) which is volatile. Alcohol is a clear, colorless, 
solution, is typically flavorful, is liquid at room temperature, and is flammable. Ethanol is categorized in two groups namely hydrated ethanol (95-96\% ethanol) and unhydrous ethanol (ethanol> 99.6\%). The second group of ethanol is ethanol which is used as fuel and is called fuel grade ethanol (FGE) [1]. Bioethanol production from plants containing glucose which is then carried out by fermentation or fermentation by adding yeast or yeast so that bioethanol is obtained as an energy source. According to [2] bioethanol production from pineapple skin extract is influenced by the type of yeast and the amount of yeast used, fermentation using bread yeast can produce higher levels of bioethanol than the use of tapai yeast. From these results it was concluded that the best variables were obtained at 4 and 5 days of fermentation with 4 grams of bread yeast from raw materials of $200 \mathrm{gr}$ pineapple skin in which bioethanol was obtained with $70 \%$ content with a volume of 16 $\mathrm{ml}$, whereas in yeast tapai the levels of bioethanol were obtained by $65 \%$ with a volume of $14 \mathrm{ml}$. This study will use papaya skin raw materials by varying the amount of yeast and fermentation time.

According to [3]. in his study Produced from Papaya Skin Fermentation that the highest bioethanol volume of $31.17 \mathrm{ml}$ was obtained during the 4-day fermentation treatment and the addition of Saccaromycescereviceae yeast by 15 grams, the highest bioethanol density was obtained at the amount of 15 gram yeast with 4 days fermentation time is $0.883 \mathrm{gr} /$ $\mathrm{ml}$, the highest media $\mathrm{pH}$ during fermentation is 5 which is found in the amount of yeast 20 grams with fermentation time of 3,4 , and 5 days. The highest yield of bioethanol was obtained at the amount of yeast 15 grams with a fermentation time of 4 days which was $6.23 \%$.

The renewable bioenergy is by bioethanol that less pollution, and able to be produced of materials containing sugar and starch such as corn, potatoes, wheat, sugar cane, molasses and others. Meanwhile, the use of agricultural land to produce bioenergy crops will compete with the cultivation of food crops. In addition, bioenergy production from cultivated plants will require higher costs compared to energy production from petroleum, and is less profitable. Therefore, alternative sources of cheap and abundant raw materials are needed [4]. Alternative sources of raw materials that can be utilized are agricultural waste and organic waste. Agricultural waste is an abundant source of natural carbon, the price is cheap and does not disturb the food chain and environmental footprint [5].

Agricultural waste and household waste include solid waste, the amount of which increases with population growth rates, industrial development, urbanization and modernization. This causes an increase in demand for food and other needs, so that waste or rubbish increases. According to the UN Food and Agriculture Organization, 1.3 billion tons of waste are produced annually from one third of the amount of food produced for human consumption. Such waste includes garbage from seafood, cereals, fruits and vegetables, products from meat and milk [6]. Organic waste is all the remnants from the household, both food and nonedible parts of natural fruits and vegetables, and are easily broken down by microorganisms. Kitchen waste increases with increasing population growth rates and urbanization which will increase average consumption. Kitchen waste can come from households, restaurants and food processing industries that produce unused food items such as left over rice, meat, fruits and vegetables, bread and other products. Kitchen waste usually contains $60 \%$ carbohydrate, $20 \%$ protein and $10 \%$ fat. The composition of the carbohydrate consists of starch, cellulose and hemicellose [7]. Municipal waste mainly consists of $65 \%$ organic waste. The dry weight content of biomass contained in organic waste is $75 \%$. In organic waste there is starch, hemicellulose, cellulose content and consists of vegetables, fruits, leaves, fruit skins, bamboo, twigs and also food scraps. Vegetable waste hydrolyzed using $1 \%$ dilute sulfuric acid and with the addition of EM4 microorganisms, then fermented using $8 \%$ Saccharomyces cereviania can produce $68.17 \%$ bioethanol [8].

Municipal waste is now a problem that must be solved immediately, given the increasing waste production every day. The biggest contributor to waste is households. The level of environmental pollution is very alarming, data from the Ministry of Environment and Forestry states that the total waste in Indonesia reaches 187.2 million tons per year. Increased population density and limited land to accommodate the remaining consumption is one of the factors causing the volume of garbage that continues to mount [6].

The problem of garbage in the city of Palembang is categorized as an emergency. Along with the increasing population density, waste production in the city of Palembang has increased and accumulated, while land to accommodate the remaining consumption is limited. Based on data from the Palembang City Environment and Sanitation Office (DLHKK), Palembang produces 600-700 tons of waste in a day. Even when the weekend can reach 900 tons per day, this will be a threat to the people in the city of Palembang. Given the very serious impact on health and the environment. The composition of municipal solid waste consists of food waste $56.86 \%$, paperboard and nappies $15.08 \%$, wood and garden waste $5.44 \%$, 
fabrics and textile products $2.67 \%$, rubber and leather $0.33 \%$, plastic $17,47 \%$, Metals $0.46 \%$, Glass $0.93 \%$, other waste $0.76 \%$ [9].

\section{METHOD}

True Experimental design Post-Test is a method of research carried out with the aim of seeing an overview of the dosage and time of ethanol production from a mixture of cassava waste by adding bread yeast activors and tape yeast. with an approach method which will then be tested descriptively and analytically [10] In this study the authors used organic waste from cassava peels taken from trash selling cassava chips from Kalidoni Palembang. The process of making research material was carried out at the Laboratory of the Department of Environmental Health of the Palembang Health Polytechnic and subsequently carried out distillation at STIFI Pharmacy Palembang. In this study, Samples of cassava skin waste were used as much as 300 grams and $100 \mathrm{ml}$ of distilled water, then added to the yeast bread and yeast tape with doses of 1.35 gr, 2.25 gr, and 3.15 gr respectively. Furthermore, allowed to stand for 4 days. After 4 days, $150 \mathrm{ml}$ of fermented water is squeezed and then ethanol is separated by the distillation process. In Figure 1 the following is a schematic of the research process

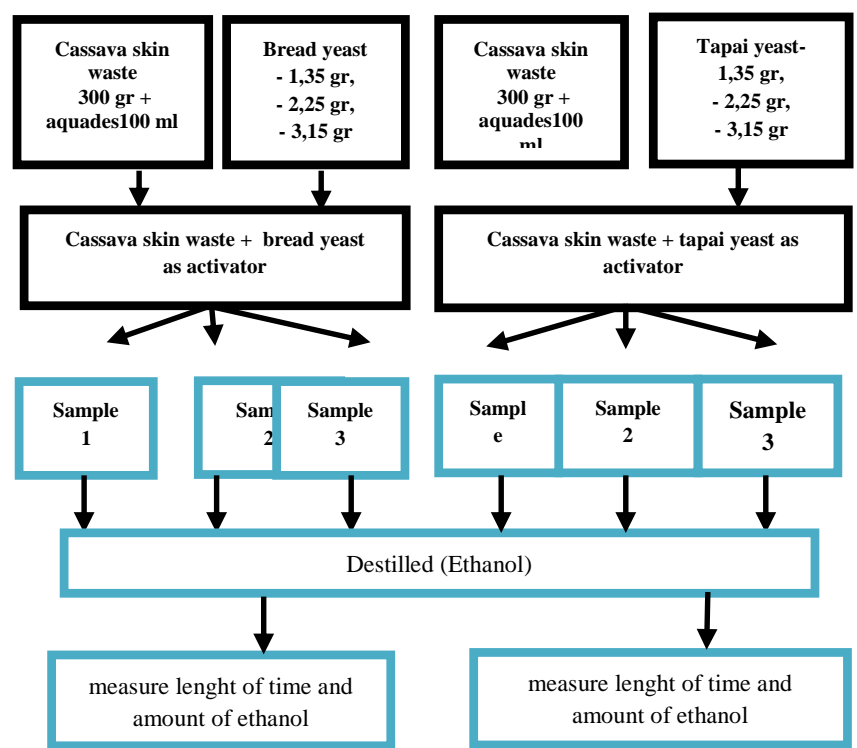

Figure 1. Schematic of the Research Process

\section{RESULTS}

Table 1 The length of time required to produce ethanolafter

\begin{tabular}{|c|c|c|c|c|c|c|}
\hline \multicolumn{2}{|c|}{ Aktivator } & \multirow{2}{*}{ 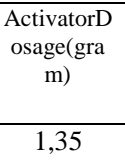 } & \multirow{2}{*}{$\begin{array}{c}\text { Cassava } \\
\text { skin waste } \\
\text { (gr) }\end{array}$} & \multirow{2}{*}{$\begin{array}{c}\text { Aquades } \\
\text { (ml) } \\
100\end{array}$} & \multirow{2}{*}{$\begin{array}{c}\begin{array}{c}\text { Amount of } \\
\text { sample (ml) }\end{array} \\
150\end{array}$} & \multirow{2}{*}{$\begin{array}{c}\begin{array}{c}\text { Length of } \\
\text { time } \\
\text { minutes) }\end{array} \\
95\end{array}$} \\
\hline & 1 & & & & & \\
\hline \multirow[t]{3}{*}{$\begin{array}{l}\text { Bread } \\
\text { yesat }\end{array}$} & 2 & 2,25 & 300 & 100 & 150 & 85 \\
\hline & 3 & 3,15 & 300 & 100 & 150 & 90 \\
\hline & 1 & 1,35 & 300 & 100 & 150 & 57 \\
\hline \multirow[t]{2}{*}{$\begin{array}{l}\text { Tapai } \\
\text { yeast }\end{array}$} & 2 & 2,25 & 300 & 100 & 150 & 58 \\
\hline & 3 & 3,15 & 300 & 100 & 150 & 67 \\
\hline
\end{tabular}

From the tableabove it is known that the minimum time needed to produce ethanol using bread yeast at a dose of 2.25 grams with a duration of 85 minutes and the longest time is at the yeast dose of $3.15 \mathrm{mg}$ for 115 minutes. Where as to produce ethanol by using yeast tapai the minimum time at a dose of 1.35 gr with a duration of 57 minutes and the longest time is at a yeast dose of $3.15 \mathrm{mg}$ for 67 minutes

Table 2 Number of ethanol produced after distillation

\begin{tabular}{|c|c|c|c|c|c|c|}
\hline Aktivator & & $\begin{array}{l}\text { Aktivator } \\
\text { Dosage } \\
\text { (gram) }\end{array}$ & $\begin{array}{l}\text { Cassava } \\
\text { skin } \\
\text { waste } \\
\text { (gr) }\end{array}$ & $\begin{array}{l}\text { Aquades } \\
(\mathrm{ml})\end{array}$ & $\begin{array}{c}\text { Amount of } \\
\text { sample (ml) }\end{array}$ & $\begin{array}{l}\text { Amount } \\
\text { of etanol } \\
\text { (ml) }\end{array}$ \\
\hline \multirow{3}{*}{$\begin{array}{l}\text { Bread } \\
\text { yesat }\end{array}$} & 1 & 1,35 & 300 & 100 & 150 & 10 \\
\hline & 2 & 2,25 & 300 & 100 & 150 & 20 \\
\hline & 3 & 3,15 & 300 & 100 & 150 & 40 \\
\hline \multirow{3}{*}{$\begin{array}{l}\text { Tapai } \\
\text { yeast }\end{array}$} & 1 & 1,35 & 300 & 100 & 150 & 20 \\
\hline & 2 & 2,25 & 300 & 100 & 150 & 15 \\
\hline & 3 & 3,15 & 300 & 100 & 150 & 50 \\
\hline
\end{tabular}

From the table above it is known that the amount of ethanol produced using the least yeast bread is on cassava skin waste with an activator dose of 1.35 grams with ethanol produced as much as $10 \mathrm{ml}$ while the most ethanol producing is on cassava skin waste at a dose activator 3.15 grams. with ethanol produced as much as $40 \mathrm{ml}$ Whereas to produce ethanol using yeast tape the least is in cassava skin waste with an activator dose of 2.25 grams with ethanol produced as much as $15 \mathrm{ml}$ while the most ethanol that produces is in cassava skin waste with an activator dose of 3.15 grams with ethanol produced as much as $50 \mathrm{ml}$. 


\section{DISCUSSION}

To produce ethanol by using bread yeast at a dose of $2.25 \mathrm{mg}$ with a duration of 85 minutes and the longest time is at a yeast dose of $3.15 \mathrm{mg}$ for 115 minutes. Whereas to produce ethanol by using a yeast tape the minimum time at a dose of $1.35 \mathrm{mg}$ with a duration of 57 minutes and the longest time is at a yeast dose of $3.15 \mathrm{mg}$ for 67 minutes, while the amount of ethanol produced using the least yeast bread is in cassava skin waste with an activator dose of 1.35 grams with ethanol produced as much as $10 \mathrm{ml}$ while the most ethanol that produces is cassava skin waste with an activator dose of 3.15 grams. with ethanol produced as much as $40 \mathrm{ml}$ Whereas to produce ethanol by using yeast tape the least is in cassava skin waste with an activator dose of 2.25 grams with ethanol produced as much as $15 \mathrm{ml}$ while the most ethanol that produces is in cassava skin waste with an activator dose of 3.15 grams with ethanol produced as much as $50 \mathrm{ml}$.

Ethanol for consumption is generally produced by fermentation or fermentation of foods containing starch or carbohydrates, such as rice tubers. Alcohol produced from the fermentation process is usually low in content. To get alcohol with higher levels of purification process is needed through distillation or distillation. Ethanol for industrial use on a larger scale is produced from drip fermentation, which is a by-product in the cane sugar or beet sugar industry. This research is in line with Sunarto's research in [11], that the process of making ethanol is influenced by raw materials, activators and nutrients.

So, researched was produced ethanol that used tapai yeast most effectived than bread yeast. Produced that used bread yeast on cassava skin waste to activator 1.35 grams got ethanol $10 \mathrm{ml}$. and to activator 3.15 grams got ethanol $40 \mathrm{ml}$. Meanwhile, the used tapai yeast with activator 2.25 grams that got ethanol $15 \mathrm{ml}$. toused activator 3.15 grams were got ethanol $50 \mathrm{ml}$.

\section{CONCLUSIONS}

Based on the results of research that has been done, the following conclusions can be drawn:1. There is no effect of the time difference in producing ethanol by using a yeast tapai activator with bread yeast 2 . There is a difference in the amount of ethanol produced using yeast tapai activator with bread yeast.

Yeast tapai is made from a mixture of rice flour with the addition of other ingredients, namely finely ground garlic, pepper, galangal, and chilies, the composition of the ingredients varies depending on the manufacture, because yeast tape is made traditionally causing various microbial compositions contained in yeast tape.

\section{ACKNOWLEDGMENT}

The author is grateful to the Institute of Researchand Community Services at Palembang Health Polytechnic who has helped fund this research.

\section{REFERENCES}

[1] Zubaidah E. Konsentrasi Inokulum Pada Pembuatan Cuka Salak ( Salacca Zalacca ) Study On Different Fermentation Condition And Inoculum Concentration In Snake Fruit Vinegar ( Salacca Zalacca ) Production. J Teknol Pertan 2010;11:94-100.

[2] Fitriani. Pemanfaatan Sari Kulit Nanas Sebagai Bahan Pembuatan Bioetanol Dengan Menggunakan Metode Fermentasi,Tga 2012.

[3] Nasrun N, Jalaluddin J, Mahfuddhah M. Pengaruh Jumlah Ragi Dan Waktu Fermentasi Terhadap Kadar Bioetanol Yang Dihasilkan Dari Fermentasi Kulit Pepaya. J Teknol Kim Unimal 2017;4:1. Https://Doi.Org/10.29103/Jtku.V4i2.68.

[4] Ma Y, Cai W, Liu Y. An Integrated Engineering System For Maximizing Bioenergy Production From Food Waste. Appl Energy 2017;206:83-9. Https://Doi.Org/10.1016/J.Apenergy.2017.08.190.

[5] Chintagunta Ad, Ray S, Banerjee R. An Integrated Bioprocess For Bioethanol And Biomanure Production From Pineapple Leaf Waste. Vol. 165. Elsevier Ltd; 2017. Https://Doi.Org/10.1016/J.Jclepro.2017.07.179.

[6] Susmiati Y. The Prospect Of Bioethanol Production From Agricultural Waste And Organic Waste. Ind J Teknol Dan Manaj Agroindustri 2018;7:67-80. Https://Doi.Org/10.21776/Ub.Industria.2018.007.02.1.

[7] Hafid Hs, Rahman Naa, Shah Ukm, Baharuddin As, Ariff Ab. Feasibility Of Using Kitchen Waste As Future Substrate For Bioethanol Production: A Review. Renew Sustain Energy Rev 2017;74:671-86. Https://Doi.Org/10.1016/J.Rser.2017.02.071.

[8] Anisah D, Herliati, Widyaningrum A. Pemanfaatan Sampah Sayuran Sebagai Bahan Baku Pembuatan Bioetanol. Pemanfaat Sampah Sayuran Sebagai Bahan Baku Pembuatan Bioetanol 2014:13-8.

[9] Departmen Of Environment And Cleanliness Of Palembang City. Palembang: 2017.

[10] Notoatmodjo S. Metodologi Penelitian Kesehatan. Jakarta: Rineka Cipta; 2010.

[11] Sari Nk. Produksi Bioethanol Dari Rumput Gajah Secara Kimia 2009;4:265-73. 